\title{
Influence of the incubation conditions on culture media to optimize primary isolation of Mycobacterium bovis
}

\section{Influência das condições de incubação nos meios de cultura para otimizar o primo isolamento de Mycobacterium bovis}

\author{
Cássia Yumi Ikuta ${ }^{1 *}$; Flávia Morato ${ }^{1}$; Gisele Oliveira de Souza ${ }^{1}$; \\ Marcos Bryan Heinemann²; Marcos Amaku³; José Soares Ferreira Neto²
}

\begin{abstract}
The isolation of Mycobacterium bovis is critical to a surveillance system for bovine tuberculosis based on detection of lesions in abattoirs. Thus, four solid culture media and three incubation conditions were investigated to elucidate which combination overcomes the others by assessing growth, time to the first appearance of colonies and their number. Ninety-seven samples of granulomatous lesions were submitted to the decontamination procedure by 1-hexadecylpyridinium chloride at $0.75 \% \mathrm{w} / \mathrm{v}$, and inoculated on two egg-based media, Stonebrink's (ST) and Löwenstein-Jensen's with sodium pyruvate (LJp), and two agar-based media, tuberculosis blood agar (B83) and Middlebrook 7H11 medium (7H11). Each medium was incubated at $37^{\circ} \mathrm{C}$ for 90 days in three incubation conditions: in air, in air containing $10 \%$ carbon dioxide $\left(\mathrm{CO}_{2}\right)$, and in air in slopes closed with burned hydrophobic cotton and subsequently plugged with a cork to create a microaerophilic atmosphere. The colonies appeared faster and in higher number when incubated in air containing $10 \% \mathrm{CO}_{2}(\mathrm{p}<0.01)$, independent of media. B83 showed a faster growth and detected more isolates at 30 days of incubation, when compared to ST (0.0178), LJp $(\mathrm{p}<0.0001)$ and $7 \mathrm{H} 11(\mathrm{p}<0.0001)$, though there was no difference between B83, ST and LJp at 60 and 90 days of incubation. $7 \mathrm{H} 11$ presented the lowest number of isolates $(\mathrm{p}<0.0001)$ and a longer period for the appearance of the first colony $(\mathrm{p}<0.001)$. According to our findings, the concomitant use of ST and B83 media incubated in air containing $10 \% \mathrm{CO}_{2}$ increases the isolation of $M$. bovis in a shorter period of time, which improves bovine tuberculosis diagnosis.
\end{abstract}

Key words: Primary isolation. Bovine tuberculosis. Mycobacterium bovis. Culture media. Incubation conditions.

\section{Resumo}

O isolamento do Mycobacterium bovis é fundamental para um sistema de vigilância para tuberculose bovina baseado na detecção de lesões em abatedouro. Assim, quatro meios de cultura sólidos e três condições de incubação foram investigados para elucidar qual combinação supera as outras através da avaliação de crescimento, tempo para o aparecimento da primeira colônia e número de colônias. Noventa e sete amostras de lesões granulomatosas foram submetidas ao processo de descontaminação por cloreto de 1 -hexadecilpiridínio a $0,75 \%$, e inoculadas em dois meios a base de ovo, Stonebrink (ST) e Löwenstein-Jensen com piruvato de sódio (LJp), e dois meios a base de ágar, ágar sangue tuberculose (B83) e Middlebrook 7H11 (7H11). Cada meio foi incubado a $37^{\circ} \mathrm{C}$ por 90 dias, em três condições de

\footnotetext{
${ }^{1}$ Pesquisadores, Faculdade de Medicina Veterinária e Zootecnia, Universidade de São Paulo, USP, São Paulo, SP, Brasil. E-mail: cassiayi@yahoo.com.br; flamorato@usp.br; ginutri@usp.br

${ }^{2}$ Profs., Faculdade de Medicina Veterinária e Zootecnia, USP, São Paulo, SP, Brasil. E-mail: marcosbryan@usp.br; jsoares@vps. fmvz.usp.br

${ }^{3}$ Prof., Faculdade de Medicina, USP, São Paulo, SP, Brasil. E-mail: amaku@vps.fmvz.usp.br

* Author for correspondence
} 
incubação: em atmosfera normal, em atmosfera com acréscimo de $10 \%$ de dióxido de carbono $\left(\mathrm{CO}_{2}\right)$, e em atmosfera normal em tubos fechados com algodão hidrófobo queimado e subsequentemente fechado com rolha para criar uma atmosfera microaerófila. As colônias apareceram mais rapidamente e em maior número quando incubadas em atmosfera com $10 \%$ de $\mathrm{CO}_{2}(\mathrm{p}<0,01)$, independente dos meios. As micobactérias cresceram em maior abundância e mais rapidamente no meio B83 aos 30 dias de incubação, comparado a ST $(0,0178)$, LJp $(\mathrm{p}<0,0001)$ e 7H11 ( $<00,0001)$, apesar de não ter havido diferença entre B83, ST e LJp aos 60 e 90 dias de incubação. 7H11 exibiu o número mais baixo de isolados $(\mathrm{p}<0,0001)$ e um período mais longo para o aparecimento da primeira colônia $(\mathrm{p}<0,001)$. De acordo com nossos resultados, o uso concomitante dos meios ST e B83, incubados em atmosfera com acréscimo de $10 \%$ de $\mathrm{CO}_{2}$, aumenta a proporção de isolados e o número de UFC de $M$. bovis, além de abreviar o tempo para aparecimento das primeiras colônias, melhorando o diagnóstico direto de tuberculose.

Palavras-chave: Primo isolamento. Tuberculose bovina. Mycobacterium bovis. Meios de cultura. Condições de incubação.

\section{Introduction}

Mycobacterium bovis is the causative agent of bovine tuberculosis, a well-known zoonosis with great socio-economic impact and public health issues. In Brazil, recent studies carried out in 13 States, which hold $75 \%$ of the Brazilian cattle population, showed prevalence of tuberculosis infected herds among $0.36 \%$, in the Federal District, and $9.0 \%$, in São Paulo (BAHIENSE et al., 2016; BARBIERI et al., 2016; DIAS et al., 2016; GALVIS et al., 2016; GUEDES et al., 2016; LIMA et al., 2016; NÉSPOLI et al., 2016; QUEIROZ et al., 2016; RIBEIRO et al., 2016; ROCHA et al., 2016; SILVA et al., 2016; VELOSO et al., 2016; VENDRAME et al., 2016). The surveillance system based on $M$. bovis isolation from suspected tuberculous lesions obtained in abattoirs is quite important for the success of the Program of Control and Eradication of Animal Brucellosis and Tuberculosis (PNCEBT) in Brazil.

For definitive diagnosis, culture media, decontamination procedures and incubation conditions have direct influence on primary isolation of M. bovis (CORNER, 1994).

Since $M$. bovis field strains require enriched media for growth on primary isolation and minimal toxicity of decontaminant reagents (CORNER, 1994), there are several studies seeking the best performance medium (SCHAEFER, 1952; BIRN, 1965; GALLAGHER; HORWILL, 1977; CORNER;
NICOLACOPOULOS, 1988; COUSINS et al., 1989), as well as for the best decontamination method (CORNER; TRAJSTMAN, 1988; AMBROSIO et al., 2008; CORNER et al., 2012).

The oxygen preference of $M$. bovis was presented in semi-solid medium by growing below the surface (LEBEK ${ }^{4}, 1959$ apud COLLINS; GRANGE, 1983). The microaerophilic characteristic has been used as one of the classical bacteriology methods to differ M. bovis from M. tuberculosis (MARKS, 1972; MARKS, 1976; COLLINS et al., 1982). However, the carbon dioxide $\left(\mathrm{CO}_{2}\right)$ requirement in the incubation atmosphere is questionable when studies without its addition presented growth (COUSINS et al., 1989), while others included $\mathrm{CO}_{2}$ and had no effect on growth rate or number of colonies (CORNER, 1994).

Despite all investigations, lack of standard and controversy exist given that the manual of international standard setting of the World Organization for Animal Health (OIE) presents only suggestions regarding a variety of media, and it is not clear about the role of $\mathrm{CO}_{2}$. The aim of the present study was to evaluate which combination of culture medium and incubation condition would

\footnotetext{
${ }^{4}$ LEBEK, G. Dependence of the oxygen optimal concentration of both strains of mammalian Mycobacterium tuberculosis on the nutritive substrate. Zentralblatt für Bakteriologie: International Journal of Medical Microbiology, Stuttgart, v. 176, p. 530-537, 1959.
} 
improve $M$. bovis recovery on primary isolation by verifying the requirement of $\mathrm{CO}_{2}$ and its effect on different solid media.

\section{Material and Methods}

Ninety-seven samples of granulomatous lesions collected from bovine abattoirs were submitted to culture. One gram of each sample was macerated in $5 \mathrm{~mL}$ sterile $0.85 \%$ saline solution. The tissue suspension was decontaminated with equal volume of 1.5\% 1-hexadecylpyridinium chloride at room temperature for 30 minutes (AMBROSIO et al., 2008), then centrifuged at $2300 \mathrm{x} g$ for 20 minutes (CORNER; TRAJSTMAN, 1988). The supernatant was discarded and the sediment resuspended with 3 $\mathrm{mL}$ sterile $0.85 \%$ saline solution. The volume used was $0.1 \mathrm{~mL}$ in each slope.

Four commonly recommended culture media were selected. Two egg-based media, Stonebrink's medium (ST) (CENTRO PANAMERICANO DE ZOONOSIS, 1985) and Löwenstein-Jensen's medium with sodium pyruvate (LJp) (CORNER; NICOLACOPOULOS, 1988), and two agar-based media, tuberculosis blood agar (B83) (CORNER; NICOLACOPOULOS, 1988) and Middlebrook 7H11 medium (7H11) (COUSINS et al., 1989), were prepared with amounts of $7.5 \mathrm{~mL}$ in slopes with screw caps and slopes closed with hydrophobic cotton.

All samples were inoculated in two slopes of each medium and incubated at $37^{\circ} \mathrm{C}$ in three different incubation conditions, totalizing 12 combinations. Slopes with loosened screw caps were incubated in air (IC-1) and in air containing $10 \% \mathrm{CO}_{2}$ (IC2 ), and slopes closed with hydrophobic cotton were incubated in air. After 24 hours, the lids were tightened, and the cotton was burned and subsequently closed with a cork to create a higher $\mathrm{CO}_{2}$ tension (IC-3) (ROSÁRIO et al., 2014). The incubation continued up to 90 days.
Every three days the slopes were examined for growth and time to the first appearance of characteristic $M$. bovis colonies. Number of colonies was scored on days 30, 60 and 90 of incubation. Ziehl-Neelsen staining was used on colonies compatible with mycobacteria. The isolates were identified as $M$. bovis by PCR-restriction fragment length polymorphism analysis (PRA) of the $h s p 65$ gene (TELENTI et al., 1993) and spoligotyping methods (KAMERBEEK et al., 1997).

For analysis, the number of colonies average was calculated from the two slopes of each sample for the 12 possible combinations of medium/incubation condition. The total of 300 colonies was adopted when they were uncountable (BRASIL, 1993).

The growth of $M$. bovis colonies was analyzed using comparison of proportions test by MedCalc program. The time to first appearance and number of colonies were analyzed using the Friedman's test, and the Dunn's test was used for multiple comparisons by GraphPad InStat program. Differences were considered statistically significant at $\mathrm{p}<0.05$.

\section{Results}

Out of the 97 samples, M. bovis colonies were isolated from $46(47.4 \%)$ for at least one of the 12 combinations. B83 showed a faster growth, followed by ST, with the mean time to the first appearance of colonies being 30 days (range: 18-78) and 37 days (range: 16-90), respectively. B83 also detected more isolates at 30 days of incubation, when compared to ST (0.0178), LJp $(p<0.0001)$ and 7H11 $(p<0.0001)$. However, there was no difference between B83, ST and LJp at 60 and 90 days of incubation (Table 1). The numbers of colonies scored on B83, ST and LJp were not significantly different, though they were superior to $7 \mathrm{H} 11(\mathrm{p}<0.0001)$. 
Table 1. Number and percentage of M. bovis isolates at 30, 60 and 90 days of incubation according to culture media.

\begin{tabular}{ccccc}
\hline Days & ST (\%) & LJp (\%) & 7H11 (\%) & B83 (\%) \\
\hline 30 & $41(14.09)$ & $21(7.22)$ & $11(3.78)$ & $64(21.99)$ \\
60 & $70(24.05)$ & $68(23.37)$ & $19(6.53)$ & $77(26.46)$ \\
90 & $76(26.12)$ & $73(25.09)$ & $21(7.22)$ & $78(26.80)$ \\
\hline
\end{tabular}

Concerning incubation conditions, IC-2 and increased the detection of isolates at 30 days of presented 31 days (range: 16-78) as the mean time to the first appearance of colonies, while IC-3 showed 38 days (range: 21-90) and IC-1 40 days (range: 27-90). Moreover, IC-2 displayed higher number of colonies during all incubation period $(\mathrm{p}<0.01)$, incubation $(\mathrm{p}<0.0001)$ (Table 2).

The type of incubation condition used had influence on the egg-based media only at the beginning of incubation (30 days), but none on the agar-based media (Table 3).

Table 2. Number and percentage of M. bovis isolates at 30, 60 and 90 days of incubation according to incubation conditions.

\begin{tabular}{cccc}
\hline Days & IC-1 (\%) & IC-2 $(\%)$ & IC-3 (\%) \\
\hline 30 & $33(8.51)$ & $76(19.59)$ & $28(7.22)$ \\
60 & $76(19.59)$ & $90(23.20)$ & $68(17.53)$ \\
90 & $81(20.88)$ & $94(24.23)$ & $73(18.81)$ \\
\hline
\end{tabular}

Table 3. Number and percentage of $M$. bovis isolates at 30, 60 and 90 days of incubation according to culture media incubation conditions.

\begin{tabular}{ccccccc}
\hline \multirow{2}{*}{ days } & \multicolumn{3}{c}{ Egg-based media } & \multicolumn{3}{c}{ Agar-based media } \\
\cline { 2 - 6 } & IC-1 (\%) & IC-2(\%) & IC-3 (\%) & IC-1 (\%) & IC-2 (\%) & IC-3 (\%) \\
\hline 30 & $11(5.67)$ & $46(23.71)$ & $4(2.06)$ & $22(11.34)$ & $29(14.95)$ & $24(12.37)$ \\
60 & $44(22.68)$ & $51(26.29)$ & $42(21.65)$ & $32(16.49)$ & $38(19.59)$ & $26(13.40)$ \\
90 & $48(24.74)$ & $54(27.84)$ & $47(24.23)$ & $32(16.49)$ & $40(20.62)$ & $26(13.40)$ \\
\hline
\end{tabular}

\section{Discussion}

The outcome of primary isolation of M. bovis depends on the choice among all available culture media, decontamination procedures and incubation conditions. The chosen combination establishes the accuracy potential to bacteriological diagnosis for bovine tuberculosis.

Culture media and incubation conditions data were analyzed separately to better assess each factor.

Overall B83, ST, LJp presented the best results compared to $7 \mathrm{H} 11$, in complete contrast to the findings of Gallagher and Horwill (1977).
B83 and ST exhibited similar results in terms of faster detection, which supports Corner's (1994) data from studies using 491 samples, though other investigations showed lower time to first appearance of colonies on 7H11 (COUSINS et al., 1989; CORNER et al., 2012) and Middlebrook 7 H11 medium with addition of antibiotics (GALLAGHER; HORWILL, 1977; CORNER; NICOLACOPOULOS, 1988).

The number of isolates and colonies were higher on B83, ST and LJp, confirming findings of previous studies (CORNER; NICOLACOPOULOS, 1988; 
COUSINS et al., 1989). According to our data, seven M. bovis isolates grew only on ST, five only on LJp and four only on B83. A resembling event occurred in Cousins et al., 1989 results, which presented 20 isolates on B83 and seven on Stonebrink's medium.

Higher concentration of $\mathrm{CO}_{2}$ is recommended as growth factor for $M$. bovis, once it is classified as microaerophilic (COLLINS et al., 1982). Although solid media assays on this matter are rare, some studies were performed under incubation in air containing $\mathrm{CO}_{2}$ (GALLAGHER; HORWILL, 1977; CORNER; NICOLACOPOULOS, 1988; CORNER; TRAJSTMAN, 1988; CORNER, 1994), despite no agreement or consistence on the concentration applied.

The attempt to create a microaerophilic atmosphere by burning hydrophobic cotton and closing the slope with a cork was proven to be ineffective to promote $M$. bovis growth.

Through incubation with controlled atmosphere, we demonstrated that 30 days incubation in air containing $10 \% \mathrm{CO}_{2}$ increased detection of $M$. bovis isolates on egg-based media, but not on agarbased media. These results partially corroborate with (Corner, Lund and Kyrwult ${ }^{5}$ 's apud CORNER; NICOLACOPOULOS, 1988) statement about incubation with $5 \% \mathrm{CO}_{2}$ increasing $M$. bovis growth on egg-based media and decreasing it on agar-based media.

Interestingly, the best performance of B83, ST and LJp was in presence of $\mathrm{CO}_{2}$ regarding higher proportion of isolates and number of colonies, and faster detection.

\section{Conclusion}

The present study provides strong evidence demonstrating the advantages of $\mathrm{CO}_{2}$ on primary isolation of $M$. bovis in solid culture media, particularly egg-based ones. The early diagnosis will improve detection of bovine tuberculosis assisting the PNCEBT in Brazil. Therefore, the use of Stonebrink's and B83 media, in parallel, incubated in air containing $10 \% \mathrm{CO}_{2}$ for at least 90 days is recommended to obtain a more effective and sensitive $M$. bovis detection.

\section{Acknowledgements}

Thanks to FAPESP and $\mathrm{CNPq}$ for financial support

\section{References}

AMBROSIO, S. R.; OLIVEIRA, E. M. D.; RODRIGUEZ, C. A. R.; FERREIRA NETO, J. S.; AMAKU, M. Comparison of three decontamination methods for Mycobacterium bovis isolation. Brazilian Journal of Microbiology, Rio de Janeiro, v. 39, n. 2, p. 241-244, 2008.

BAHIENSE, L.; ÁVILA, L. N. de; BAVIA, M. E.; AMAKU, M.; DIAS, R. A.; GRISI-FILHO, J. H. H.; FERREIRA, F.; TELLES, E. O.; GONÇALVES, V. S. P.; HEINEMANN, M. B.; FERREIRA NETO, J. S. Prevalence and risk factors for bovine tuberculosis in the State of Bahia, Brazil. Semina: Ciências Agrárias, Londrina, v. 37, n. 5, p. 3549-3560, 2016. Suplemento 2.

BARBIERI, J. M.; OLIVEIRA, L. F.; DORNELES, E. M. S.; MOTA, A. L. A. A.; GONÇALVES, V. S. P.; MALUF, P. P.; FERREIRA NETO, J. S.; FERREIRA, F.; DIAS, R. A.; TELLES, E. O.; GRISI-FILHO, J. H. H.; HEINEMANN, M. B.; AMAKU, M.; LAGE, A. P. Epidemiological status of bovine tuberculosis in the state of Minas Gerais, Brazil, 2013. Semina: Ciências Agrárias, Londrina, v. 37, n. 5, p. 3531-3548, 2016. Suplemento 2 .

BIRN, K. J. Blood medium for the isolation of tubercle bacilli. British Veterinary Journal, London, v. 121, n. 9, p. 437-441, 1965.

BRASIL. Ministério da Agricultura, do Abastecimento e da Reforma Agrária. Portaria ${ }^{\circ}$ 101, de 17.08.93. Métodos de Análise Microbiológica para Alimentos. 1991/1992 - 2. rev. Brasília: Ministério da Agricultura, do Abastecimento e da Reforma Agrária, 1993. 136 p.

CENTRO PANAMERICANO DE ZOONOSIS - CPZ. Tuberculosis. Bacteriologia de la tuberculosis: el cultivo del Mycobacterium tuberculosis. Buenos Aires: CPZ, 1985. 25 p. (Nota técnica, 27).

\footnotetext{
5 CORNER; LUND; KYRWULT. Unpublished data [s.d.].
} 
COLLINS, C. H.; GRANGE, J. M. A review the bovine tubercle bacillus. Journal of Applied Bacteriology, Oxford, v. 55, n. 1, p. 13-29, 1983.

COLLINS, C. H.; YATES, M. D.; GRANGE, J. M. Subdivision of Mycobaterium tuberculosis into five variants for epidemiological purposes: methods and nomenclature. The Journal of Hygiene, London, v. 89, n. 2, p. 235-242, 1982.

CORNER, L. A. Post mortem diagnosis of Mycobacterium bovis infection in cattle. Veterinary Microbiology, Amsterdam, v. 40, n. 1-2, p. 53-63, 1994.

CORNER, L. A.; NICOLACOPOULOS, C. Comparison of media used for the primary isolation of Mycobacterium bovis by veterinary and medical diagnostic laboratories. Australian Veterinary Journal, Sydney, v. 65, n. 7, p. 202-205, 1988.

CORNER, L. A.; TRAJSTMAN, A. C. An evaluation of 1-Hexadecylpyridinium Chloride as a decontaminant in the primary isolation of Mycobacterium bovis from bovine lesions. Veterinary Microbiology, Amsterdam, v. 18, n. 2, p. 127-134, 1988.

CORNER, L. A. L.; GORMLEY, E.; PFEIFFER, D. U. Primary isolation of Mycobacterium bovis from bovine tissues: conditions for maximising the number of positive cultures. Veterinary Microbiology, Amsterdam, v. 156, n. 1-2, p. 162-171, 2012.

COUSINS, D. V.; FRANCIS, B. R.; GOW, B. L. Advantages of a new agar medium in the primary isolation of Mycobacterium bovis. Veterinary Microbiology, Amsterdam, v. 20, n. 1, p. 89-95, 1989.

DIAS, R. A.; STANOJLOVIC, F. M. U.; BELCHIOR, A. P. C.; FERREIRA, R. S.; GONÇALVES, R. C.; AGUIAR, R. S. C. B.; SOUSA, P. R.; SANTOS, A. M. A.; AMAKU, M.; FERREIRA, F.; TELLES, E. O.; GRISI-FILHO, J. H. H.; GONÇALVES, V. S. P.; HEINEMANN, M. B.; FERREIRA NETO, J. S. Prevalence and risk factors for bovine tuberculosis in the state of São Paulo, Brazil. Semina: Ciências Agrárias, Londrina, v. 37, n. 5, p. 3673-3684, 2016. Suplemento 2.

GALLAGHER, J.; HORWILL, D. M. A selective oleic acid albumin agar medium for the cultivation of Mycobacterium bovis. The Journal of Hygiene, London, v. 79 , n. 1, p. 155-160, 1977.

GALVIS, J. O. A.; GRISI-FILHO, J. H. H; COSTA, D.; SAID, A. L. P. R.; AMAKU, M.; DIAS, R. A.; FERREIRA, F.; GONÇALVES, V. S. P.; HEINEMANN, M. B.; TELLES, E. O.; FERREIRA NETO, J. S. Epidemiologic characterization of bovine tuberculosis in the state of Espírito Santo, Brazil. Semina: Ciencias
Agrárias, Londrina, v. 37, n. 5, p. 3567-3578, 2016. Suplemento 2.

GUEDES, I. B.; BOTTENE, I. F. N.; MONTEIRO, L. A. R. C.; LEAL FILHO, J. M.; HEINEMANN, M. B.; AMAKU, M.; GRISI-FILHO, J. H. H.; DIAS, R. A.; FERREIRA, F.; TELLES, E. O.; GONÇALVES, V. S. P.; FERREIRA NETO, J. S. Prevalence and risk factors for bovine tuberculosis in the state of Mato Grosso do Sul, Brazil. Semina: Ciências Agrárias, Londrina, v. 37, n. 5, p. 3579-3588, 2016. Suplemento 2.

KAMERBEEK, J.; SCHOULS, L.; KOLK, A.; VAN AGTERVELD, M.; VAN SOOLINGEN, D.; KUIJPER, S.; BUNSCHOTERN, A.; MOLHUIZEN, H.; SHAW, R.; GOYAL, M.; VAN EMBDEN, J. Simultaneous detection and strain differentiation of Mycobacterium tuberculosis for diagnosis and epidemiology. Journal of Clinical Microbiology, Washington, v. 35, n. 4, p. 907-914, 1997.

LIMA, P. B.; NASCIMENTO, D. L.; ALMEIDA, E. C.; PONTUAL, K. A. Q.; AMAKU, M.; DIAS, R. A.; FERREIRA, F.; GONÇALVES, V. S. P.; TELLES, E. O.; GRISI-FILHO, J. H. H.; HEINEMANN, M. B.; SILVA, J. C. R.; FERREIRA NETO, J. S. Epidemiological situation of bovine tuberculosis in the state of Pernambuco, Brazil. Semina: Ciências Agrárias, Londrina, v. 37, n. 5, p. 3601-3610, 2016. Suplemento 2.

MARKS, J. A system for the examination of tubercle bacilli and other mycobacteria. Tubercle, London, v. 57, n. 3, p. 207-225, 1976.

Classification of mycobacteria in relation to clinical significance. Tubercle, London, v. 53, n. 4, p. 259-264, 1972.

NÉSPOLI, J. M. B.; NEGREIROS, R. L.; AMAKU, M.; DIAS, R. A.; FERREIRA, F.; TELLES, E. O.; HEINEMANN, M. B.; GRISI-FILHO, J. H. H.; GONÇALVES, V. S. P.; FERREIRA NETO, J. S. Epidemiological situation of bovine tuberculosis in the state of Mato Grosso, Brazil. Semina: Ciências Agrárias, Londrina, v. 37, n. 5, p. 3589-3600, 2016. Suplemento 2.

QUEIROZ, M. R.; GROFF, A. C. M.; SILVA, N. S.; GRISI-FILHO, J. H. H.; AMAKU, M.; DIAS, R. A.; TELLES, E. O.; HEINEMANN, M. B.; FERREIRA NETO, J. S.; GONÇALVES, V. S. P. FERREIRA, F. Epidemiological status of bovine tuberculosis in the state of Rio Grande do Sul, Brazil. Semina: Ciências Agrárias, Londrina, v. 37, n. 5, p. 3647-3658, 2016. Suplemento 2.

RIBEIRO, L. A.; GONÇALVES, V. S. P.; FRANCISCO, P. F. C.; MOTA, A. L. A. A.; NASCIMENTO, G. T.; LICURGO, J. B.; FERREIRA, F.; GRISI-FILHO, J. H. H.; FERREIRA NETO, J. S.; AMAKU, M.; DIAS, R. A.; TELLES, E. O.; HEINEMANN, M. B.; BORGES, J. R. 
J. Epidemiological status of bovine tuberculosis in the Federal District of Brazil. Semina: Ciências Agrárias, Londrina, v. 37, n. 5, p. 3561-3566, 2016. Suplemento 2.

ROCHA, W. V.; JAYME, V. S.; MOTA, A. L. A. A.; BRITO, W. M. E. D; PIRES, G. R. C; GRISI-FILHO, J. H. H; DIAS, R. A.; AMAKU, M.; TELLES, E. O.; HEINEMANN, M. B.; FERREIRA, F.; FERREIRA NETO, J. S.; GONÇALVES, V. S. P. Prevalence and herd-level risk factors of bovine tuberculosis in the State of Goiás, Brazil. Semina: Ciências Agrárias, Londrina, v. 37, n. 5, p. 3625-3628, 2016. Suplemento 2.

ROSÁRIO, T. R.; DIB, C. C.; ROXO, E.; PINHEIRO, S. R.; VASCONCELLOS, S. A.; BENITES, N. R. Thin layer microcolony culture associated with PCR for early identification of Mycobacterium bovis. Brazilian Journal of Microbiology, Rio de Janeiro, v. 45, n. 1, p. 225-230, 2014.

SCHAEFER, W. B. Growth requirements of dysgonic and eugonic strains of Mycobacterium tuberculosis var. bovis. The Journal of Experimental Medicine, New York, v. 96, n. 3, p. 207-219, 1952.

SILVA, M. C. P.; GONÇALVES, V. S. P.; MOTA, A. L. A. A.; KOLODA, M.; FERREIRA NETO, J. S.; GRISIFILHO, J. H. H; DIAS, R. A.; AMAKU, M.; TELLES, E. O.; FERREIRA, F.; HEINEMANN, M. B.; ALFIERI,
A. A.; MULLER, E. E. Prevalence and herd-level risk factors for bovine tuberculosis in the state of Paraná, Brazil. Semina: Ciências Agrárias, Londrina, v. 37, n. 5, p. 3611-3624, 2016. Suplemento 2.

TELENTI, A.; MARCHESI, F.; BALZ, M.; BALLY, F.; BÖTTGER, E. C.; BODMER, T. Rapid identification of mycobacteria to the species level by polymerase chain reaction and restriction enzyme analysis. Journal of Clinical Microbiology, Washington, v. 31, n. 2, p. 175178, 1993.

VElOSO, F. P.; BAUMGARTEN, K. D.; MOTA, A. L. A. A.; FERREIRA, F.; FERREIRA NETO, J. S.; GRISI-FILHO, J. H. H.; DIAS, R. A.; AMAKU, M.; TELLES, E. O.; HEINEMANN, M. B.; GONÇALVES, V. S. P. Prevalence and herd-level risk factors of bovine tuberculosis in the State of Santa Catarina, Brazil. Semina: Ciências Agrárias, Londrina, v. 37, n. 5, p. 3659-3672, 2016. Suplemento 2.

VENDRAME, F. B.; AMAKU, M.; FERREIRA, F.; TELLES, E. O.; GRISI-FILHO, J. H. H.; GONÇALVES, V. S. P.; HEINEMANN, M. B.; FERREIRA NETO, J. S.; DIAS, R. A. Epidemiologic characterization of bovine tuberculosis in the State of Rondônia, Brazil. Semina: Ciências Agrárias, Londrina, v. 37, n. 5, p. 3639-3646, 2016. Suplemento 2. 
